\title{
Compulsory Licenses and Government Use: Challenges and Opportunities
}

\author{
Yousuf A. Vawda
}

\begin{abstract}
The compulsory licensing and government use flexibility is potentially the most powerful tool available under the TRIPS Agreement, as amplified by the Doha Declaration, to advance public health objectives. Yet, many lower and middle income countries have shown an apparent reluctance to both incorporate them into their national legislation and then utilise them-except in a relatively small number of cases. This contribution analyses the circumstances surrounding this phenomenon. It outlines the context, historical roots of compulsory licensing and its inclusion on the TRIPS Agreement, recent examples of its utility including in two sub-Saharan countries affected by HIV/AIDS, and offers some recommendations. Among the propositions advanced are that the use of such flexibilities is not an insurmountable problem (as the case of Zimbabwe illustrates) and that in the longer term, public health objectives are best advanced by, among others, amending the TRIPS Agreement to exempt health technologies from the ambit of intellectual property protection, and new, alternative models for rewarding innovation in this field of technology being introduced.
\end{abstract}

\section{Introduction}

This paper is a contribution to the debate on the role of compulsory licensing and government use to promote access to medicines, and is situated within the context of the universally accepted right of access to health care and medicines. ${ }^{1}$ These are two types of authorisation issued to either third parties or the government itself to make use of a patented invention without the consent of the patent holder, under defined circumstances.

\footnotetext{
${ }^{1}$ For present purposes, the term 'medicines' includes pharmaceutical and biologic products, vaccines, diagnostics and related technologies.
}

Y. A. Vawda $(\square)$

School of Law, University of KwaZulu-Natal, Durban, South Africa

e-mail: vawday@ukzn.ac.za 
Despite the fact that international law unequivocally establishes access to healthcare as a fundamental right, ${ }^{2}$ this right has achieved recognition mostly in theory. The consistent prioritisation by states and multinational corporations of enforcement of intellectual property (IP) rights over promoting access to medicines, has resulted in health technologies becoming increasingly inaccessible. This is largely because of the monopoly pricing of many life-saving medicines-which has rendered them unaffordable and endangered public goods. ${ }^{3}$ Such an indictment has been met by the proponents of strong IP protection with the counterclaim that certain provisions in international instruments secure IP protection as a human right. They often cite, in support, the recognition in the ICESCR of the right to the 'protection of the moral and material interests resulting from any scientific, literary or artistic production of which he is author'. 'However, this sub-article must not be read in isolation, and is counterbalanced by another, which recognises everyone's right 'to enjoy the benefits of scientific progress and its applications" ${ }^{, 5}$ which, it is argued, must trump any IP claims.

This tension between IP protection and access to health has been the subject of a number of international commissions and, most recently, the UN Secretary-General's High Level Panel on Access to Medicines in 2016. ${ }^{6}$ One of the Panel's key recommendations directly references the need for adoption and use of compulsory licensing legislation:

Governments should adopt and implement legislation that facilitates the issuance of compulsory licenses. Such legislation must be designed to effectuate quick, fair, predictable and implementable compulsory licenses for legitimate public health needs, and particularly with regards to essential medicines. The use of compulsory licensing must be based on the provisions found in the Doha Declaration and the grounds for the issuance of compulsory licenses left to the discretion of governments. ${ }^{7}$

It is in this context that compulsory licences and government use provisions in IP law are advanced as both important safeguards against abusive practices by IP rights holders, and enablers of the public's right to access medicines at affordable prices.

In theory, the compulsory licence and government use flexibility is one of the most powerful tools available under the 1994 WTO Agreement on Trade Related

\footnotetext{
${ }^{2}$ For example, in the Universal Declaration of Human Rights https://www.ohchr.org/EN/UDHR/ Documents/UDHR_Translations/eng.pdf (UDHR), the International Covenant on Economic Social and Cultural Rights https://www.ohchr.org/Documents/ProfessionalInterest/cescr.pdf (ICESCR), and a host of other international and regional instruments.

${ }^{3}$ Vawda and Baker (2013). http://www.scielo.org.za/scielo.php?script=sci_arttext\&pid=S199620962013000100004 \#top119.

${ }^{4}$ UDHR, art 27(2) and ICESCR art 15(1)(c).

${ }^{5}$ ICESCR, art 15(1)(b).

${ }^{6}$ United Nations (2016), http://www.unsgaccessmeds.org/final-report.

${ }^{7}$ United Nations (2016), recommendation 2.6.1 (b). In addition, recommendation 2.6.1 (c) urges the revision and adoption of the paragraph 6 decision.
} 
Aspects of Intellectual Property Rights (TRIPS Agreement) ${ }^{8}$ (as amplified by the Doha Declaration ${ }^{9}$ ) to advance public health objectives. This is because is removes the patent holder's exclusive right to work the patent. Despite these options having been recognised internationally since as far back as the Paris Convention in $1883^{10}$ (as elaborated below), and more recently in Article 31 of the TRIPS Agreement, and with increasing use particularly in the wake of the HIV/AIDS pandemic, many lower and middle income countries (LMICs) have shown an apparent reluctance to fully engage with these mechanisms. They have firstly, not universally incorporated these and other flexibilities into their national legislation and, secondly, where they are available in their legislation, failed or refused to utilise them-except in a relatively small number of cases. ${ }^{11}$

"The lack of appropriate national legislation for the full implementation of such flexibilities remains one of the greatest difficulties for some developing countries. At the international level, there is a need to improve the legal and technical assistance offered to these countries with respect to intellectual property and public health. In the 16 years since the Doha Declaration, technical assistance has been insufficient or inappropriate."12 This comment highlights the twin problems of the failure to incorporate the flexibilities in national legislation, and the lack of sufficient and, importantly, appropriate technical assistance.

There are of course multiple other difficulties to be surmounted. They include: political and economic pressures by countries which house IP-rich industries not to use the flexibilities; ${ }^{13}$ the lack of political will by the governments of LMICs, as well as of some regional IP organisations, ${ }^{14}$ the lack of technical, legal and regulatory capacity to process such applications; and the legal and judicial culture existent in

\footnotetext{
${ }^{8}$ Trade-Related Aspects of Intellectual Property Rights [WTO] https://www.wto.org/english/docs_ e/legal_e/27-trips_03_e.htm.

${ }^{9}$ Declaration on the TRIPS agreement and public health [WTO] https://www.wto.org/english/ thewto_e/minist_e/min01_e/mindecl_trips_e.htm.

${ }^{10}$ As elaborated below in Sect. 2.

${ }^{11}$ See, for example, Ellen 't Hoen, The Global Politics of Pharmaceutical Monopoly Power. Drug patents, access, innovation and the application of the WTO Doha Declaration on TRIPS and Public Health (2009) https://www.msfaccess.org/sites/default/files/MSF_assets/Access/Docs/ACCESS_ book_GlobalPolitics_tHoen_ENG_2009.pdf.

${ }^{12}$ Correa and Velasquez (2019) South Centre Research Papers 85 https://www.southcentre.int/wpcontent/uploads/2019/04/RP85_Access-to-Medicines-Experiences-with-Compulsory-Licensesand-Government-Use-The-Case-of-Hepatitis-C_EN.pdf.

${ }^{13}$ This problem was most recently highlighted in the case of Colombia's attempts to issue a compulsory licence on imatinib, as indicated by its Minister of Health to a meeting of the World Health Assembly. See WIPO (2017) WIPO Standing Committee on the Law of Patents https:// www.wipo.int/edocs/mdocs/scp/en/scp_27/scp_27_6.pdf, 3 .

${ }^{14}$ Sangeeta Shashikant, "The African Regional Intellectual Property Organization (ARIPO) Protocol on Patents: Implications for Access to Medicines" [2014] South Centre Research Paper No 56,6 .
} 
many countries whose intellectual property law has its genesis in the period of colonialism. $^{15}$

This paper's sights are more modest. It reviews the distinct responses of two countries caught in the epicentre of the HIV/AIDS pandemic in sub-Saharan Africa (namely Zimbabwe and South Africa), to understand their respective approaches to the use of compulsory licensing and government use and the barriers that need to be confronted, and to explore some future directions for policy and legal reform in this thematic area.

\section{Historical and Conceptual Roots}

A compulsory licence is an authorisation granted by a government allowing third parties to produce a patented product or to utilise a patented process without the consent of the patent holder, and which use will not amount to an infringement of the patent. The grant of a compulsory licence constitutes a proactive governmental intervention when market forces result in a disequilibrium between the objectives of rewarding innovation and ensuring social and economic welfare. ${ }^{16}$ They 'ensure an efficient operation of innovation markets by avoiding the risk that patents themselves become barriers to invention and innovation ... (and) ... (a)s policy tools, compulsory licences help to ensure that patent protection remains properly balanced with other socio-economic interests. ${ }^{17}$

The first iteration of the term 'compulsory licence' in an international instrument is to be found in the Paris Convention of $1883^{18}$ which, although it does not itself define the term, provides for its grant 'to prevent the abuses which might result from the exercise of the exclusive rights conferred by the patent, for example, failure to work. ${ }^{, 19}$ The earliest recorded references to compulsory licences are found in the Venice Patent Law of $1474 .^{20}$ This was followed by the UK Statute of Monopolies of 1623 and has, over the past few centuries, been received into the national laws of many jurisdictions. ${ }^{21}$ In similar vein, 'government use' or 'crown use' is a grant by

\footnotetext{
${ }^{15}$ Vawda (2018) South Centre Research Papers 90, 16-18.

${ }^{16}$ For a history of the evolution of intellectual property, compulsory licences and related issues, see May and Sell (2006).

${ }^{17}$ Max Planck Institute (2014), p. 9 https://www.mpg.de/8133454/Patent-Declaration1.pdf.

${ }^{18}$ Paris Convention for the Protection of Industrial Property of March 20, 1883 https://www.wipo. int/edocs/lexdocs/treaties/en/paris/trt_paris_001en.pdf.

${ }^{19}$ Paris Convention for the Protection of Industrial Property of March 20, 1883, art 5A(2).

${ }^{20}$ See Editorial (2012) http://thailawforum.com/articles/Trips-and-access-to-medicines-Indiaand-Thailand-2.html.

${ }^{21}$ Correa (1999) Trade-Related Agenda, Development and Equity, Working Papers https://www. iatp.org/sites/default/files/Intellectual_Property_Rights_and_the_Use_of_Co.pdf. accessed 26 January 2020. For a background of the use of compulsory licensing in other jurisdictions, see Ellen 't Hoen, The Global Politics of Pharmaceutical Monopoly Power. Drug patents, access,
} 
the government, to itself or other entities or contractees acting on behalf of government, to make use of a patented product or process without the consent of the patent holder. Its origin is frequently attributed to UK law. ${ }^{22}$ In both instances of compulsory licences and government use, a royalty is required to be paid to the patent holder. ${ }^{23}$ In the case of compulsory licences, prior negotiation for a voluntary licence on reasonable commercial terms and within a reasonable period of time is also a requirement. ${ }^{24}$ This requirement is waived in cases of national emergency or other circumstances of extreme urgency, or in cases of public non-commercial use (government use $)^{25}$ or to remedy a practice that has been determined after a judicial or administrative process to be anti-competitive. ${ }^{26}$

The availability and use of compulsory licensing in the pharmaceutical sector was apparently limited during the early twentieth century, as many countries excluded such products from patentability. ${ }^{27}$ Nonetheless, there are examples of its use in industrialised countries, for example, early instances of use in Canada ${ }^{28}$ resulted in some of the lowest prices for medicines, while in the $\mathrm{UK}^{29}$ the 'crown use' provisions have been effectively deployed to secure generic medicines for the National Health Service. The US, ${ }^{30}$ too, has a long history of government use licences under 28 U.S.C. section 1498, especially for federal programmes involving defence equipment as well as medicines. In terms of this expeditious provision, the government was able to procure cheaper generic drugs in the 1960s at less than $1 \%$ of their list price together with a reasonable royalty. ${ }^{31}$ And recently, during the 2001 anthrax

innovation and the application of the WTO Doha Declaration on TRIPS and Public Health (2009), 41-44.

${ }^{22}$ Patents, Designs, and Trade Marks Act of 1883, s 27(2) https://archive.org/stream / patentsdesignsa01britgoog/patentsdesignsa01britgoog_djvu.txt.

${ }^{23}$ Trade-Related Aspects of Intellectual Property Rights [WTO], art 31(h) requires the payment of 'adequate remuneration'.

${ }^{24}$ Trade-Related Aspects of Intellectual Property Rights [WTO], art 31(b).

${ }^{25}$ Trade-Related Aspects of Intellectual Property Rights [WTO], art 31(b).

${ }^{26}$ Trade-Related Aspects of Intellectual Property Rights [WTO], art 31(k).

${ }^{27}$ Ellen 't Hoen, The Global Politics of Pharmaceutical Monopoly Power. Drug patents, access, innovation and the application of the WTO Doha Declaration on TRIPS and Public Health (2009), 40.

${ }^{28}$ Ellen 't Hoen, The Global Politics of Pharmaceutical Monopoly Power. Drug patents, access, innovation and the application of the WTO Doha Declaration on TRIPS and Public Health (2009), 41.

${ }^{29}$ Ellen 't Hoen, The Global Politics of Pharmaceutical Monopoly Power. Drug patents, access, innovation and the application of the WTO Doha Declaration on TRIPS and Public Health (2009), 42.

${ }^{30}$ Ellen 't Hoen, The Global Politics of Pharmaceutical Monopoly Power. Drug patents, access, innovation and the application of the WTO Doha Declaration on TRIPS and Public Health (2009), 43.

${ }^{31}$ Brennan et al. (2016) “A Prescription for Excessive Drug Pricing: Leveraging Government Patent Use for Health (2016), p. 275 https://yjolt.org/sites/default/files/kapczynski_18yjolt275_gk_0_0. pdf. 
scare, Canada and the US were willing to consider invoking this flexibility, as has Italy on a number of occasions on anti-trust grounds. ${ }^{32}$

\section{The TRIPS Framework}

Article 31 (a) to (1) of the TRIPS Agreement provides for the grant of compulsory licences provided certain conditions are satisfied and procedures followed. These are:

- Each case must be considered on its individual merits;

- The proposed user must have made a prior attempt to obtain a voluntary licence from the right holder on reasonable commercial terms, which attempt has not been successful within a reasonable period of time. This requirement is waived (1) in the cases of national emergency or other circumstances of extreme urgency, or in cases of public non-commercial use, although the right holder must be notified; and (2) where a compulsory licence has been granted to remedy anti-competitive practices;

- The scope and duration of use is limited to the purpose for which the use was authorised and such authorisation shall be terminated if and when the circumstances which led to the use cease to exist and are unlikely to recur, subject to the legitimate interests of the licensee being protected;

- The use is non-exclusive, and is non-assignable except with that part of the enterprise or goodwill which enjoys such use;

- The use is to be predominantly for the supply of the domestic market, except when the compulsory licence is issued to remedy anti-competitive practices. (There is now an additional exception for countries with little or no manufacturing capacity under Article 31 bis);

- The patent holder must be paid adequate remuneration for such use taking into account the economic value of the authorisation, but compensation may be adjusted downwards when a compulsory licence is issued to remedy anticompetitive practices;

- The legal validity of any decision relating to the authorisation of the use, as well as the amount of remuneration, is subject to judicial or other independent review by a "distinct higher authority" in that country; and

- The right holder of a second patent that cannot be exploited without infringing the first patent may receive a licence if the second invention involves an important technical advance of considerable economic significance in relation to the first invention. In such instances, the owner of the first patent shall be entitled to a cross-licence to the second invention on reasonable terms, and the use authorised

\footnotetext{
${ }^{32}$ Ellen 't Hoen, The Global Politics of Pharmaceutical Monopoly Power. Drug patents, access, innovation and the application of the WTO Doha Declaration on TRIPS and Public Health (2009), $41-42$.
} 
in the licence on the first invention shall not be assigned without assignment of the second patent.

Article 31 of the TRIPS Agreement does not specify or otherwise limit the grounds upon which licences can be granted. This clarification was one of the key outcomes of the Doha Declaration, namely that each country has the right to grant compulsory licences, to determine the grounds on which to grant them, and to determine what constitutes an emergency or other circumstances of extreme urgency, notably public health crises with no restrictions as to disease coverage or frequency of use. ${ }^{33}$ In addition, the TRIPS Council was mandated to find a solution to the problem encountered by countries with insufficient or no manufacturing capacity in their potential use of the compulsory licensing provisions of Article 31. ${ }^{34}$ Finally, the Declaration reiterated the freedom of countries to adopt the exhaustion regime of their choice (in order to facilitate parallel importation). ${ }^{35}$

In the wake of the HIV/AIDS pandemic, and buoyed by the Doha Declaration's pro-public health interpretation of the TRIPS Agreement, a significant number of developing countries and LDCs afflicted by this crisis issued a combination of compulsory licences and government use orders to facilitate the acquisition of antiretroviral medicines (ARVs) and, occasionally, medicines for other conditions. Such countries include Brazil, Ecuador, Eritrea, Ghana, India, Indonesia, Malaysia, Mozambique, Thailand, Zambia and Zimbabwe. ${ }^{36}$ Further discussion of such use is undertaken below.

Compulsory licences are generally available on a variety of grounds, most notably in relation to patents where the patentee is found to have abused its rights in one manner or another, for example, by excessive pricing, refusals to license, or failure to work, but also where the government wants to ensure alternate sources of medicines supply, to facilitate co-formulations, or even to promote local production. Countries might also consider including judicial licences as an alternative remedy to interdicts in claims of infringement. ${ }^{37}$

\footnotetext{
${ }^{33}$ Doha Declaration paragraphs $4 \mathrm{~b}$ and $4 \mathrm{c}$.

${ }^{34}$ The solution proposed and now codified in Article 31 bis entails onerous procedural requirements on both importing and exporting countries, and has been used only once. See Correa (2019) South Centre Policy Brief N0 57 https://www.southcentre.int/wp-content/uploads/2019/01/PB57_Willthe-Amendment-to-the-TRIPS-Agreement-Enhance-Access-to-Medicines_EN-1.pdf.

${ }^{35}$ Doha Declaration paragraph 4d.

${ }^{36}$ See Khor (2014), p. 24.

${ }^{37}$ See, for example, United Nations Development Programme (2013), p. 39 https://www.undp.org/ content/dam/undp/library/hivaids/English/using_law_to_accelerate_treatment_access_in_south_ africa_undp_2013.pdf accessed 26 January 2020. This option is discussed in some detail below in the section 'The South Africa case'. (See also, further discussion on judicial licences below).
} 
Table 1 Use of flexibilities against type. Adapted from Medicines Law and Policy (note 38)

\begin{tabular}{l|c}
\hline Flexibility utilised or intended & Number of uses \\
\hline TRIPS Art 31 (compulsory licensing, public non-commercial use) & 105 \\
\hline Doha Declaration Para 7 (LDC pharmaceutical transition period provision) & 46 \\
\hline TRIPS Art 30 (patent exception) & 3 \\
\hline Doha Declaration Para 5(d) (parallel importation) & 1 \\
\hline TOTAL & 155 \\
\hline
\end{tabular}

\section{A Scan of the Use of TRIPS Flexibilities}

The most comprehensive data currently available on the use of flexibilities are those compiled by Medicines Law and Policy. ${ }^{38}$ It records some 155 instances of the use of various TRIPS flexibilities since 2001 in 82 countries across the spectrum of WTO classification (least developed countries, developing countries, high-income countries).

In terms of the relevant flexibility invoked, the majority (105) were in respect of compulsory licensing and government use, followed by the LDC pharmaceutical transition period provision (46), which provides a total waiver from recognizing or enforcing pharmaceutical patents and data protections (Table 1).

A recent update by the South Centre records further uses of compulsory licensing in Russia, in 2019, and Israel, in 2020, the latter in the wake of the COVID-19 pandemic. $^{39}$

It is evident that the compulsory licensing and government use flexibility is most favoured by countries seeking to enhance access to medicines, with some of them invoking a public health emergency as the basis for their decision. ${ }^{40}$

Thailand and Ecuador feature as the countries which have made the most frequent use of TRIPS flexibilities, in some 11 instances each. Thailand's example of government use licences is instructive for the manner in which it marshalled the synergies among evidence-based research and analysis, public mobilisation by civil society, and leadership by politicians and policy makers to 'move the mountain'. ${ }^{1}$ The effects of the licences issued between 2006 and 2007 on the prices of various medicines have been substantial. The price for the ARV efavirenz dropped by more than 7 times, and lopinavir/ritonavir by 3 times; for the anti-platelet clopidogril by 50 times; and for the anti-cancer drugs docetaxel and letrazole by 24 and 70 times

\footnotetext{
${ }^{38}$ Medicines Law and Policy, "The TRIPS Flexibilities Database" http://tripsflexibilities. medicineslawandpolicy.org/.

${ }^{39}$ See South Centre, "Compulsory Licences and Government Use of Patented Medicines: Precedents Relevant to Address COVID-19" https://ipaccessmeds.southcentre.int/covid-19-pandemic/. ${ }^{40}$ See Khor (2014). Of the 12 countries surveyed Ghana, Mozambique, Eritrea and Zimbabwe premised their licences on the emergency ground.

${ }^{41}$ Wibulpolprasert et al. (2011) https://www.ncbi.nlm.nih.gov/pmc/articles/PMC3180369/.
} 
respectively. ${ }^{42}$ Indonesia is another country with multiple uses, having issued compulsory licences for the supply of ARVs on 3 occasions. ${ }^{43}$

According to the TRIPS Flexibilities Database, 40 of the 46 instances of the use of flexibilities by LDCs related to the LDC transition provision. With the exception of Bangladesh ${ }^{44}$ there does not appear to be any instances of the use of this flexibility prior to the Doha Declaration. It is therefore significant that there has been a surge in the use of this flexibility post-Doha. Additionally, in terms of the most recent extension of the waiver until 2033, the exemption relates not only to pharmaceutical patents, but also to data protection, mailbox obligations and market exclusivity. ${ }^{45}$

Reference has been made to the lack of appropriate technical advice to countries, when formulating their IP laws, in relation to their use of public health flexibilities. In this regard, the situation of the African Regional Intellectual Property Organisation (ARIPO) is instructive. A 2014 study on the ARIPO Protocol on Patents ${ }^{46}$ revealed that the effective use of TRIPS flexibilities by countries in the East African Community (EAC), for example, has been constrained by the workings of ARIPO, which processes the majority of patent applications for that region. Further, that its current modus operandi 'does not facilitate the full use of TRIPS flexibilities and instead erects patent barriers to the importation and local production of affordable medicines. ${ }^{47}$ A recent analysis by Baker of the ARIPO-commissioned 'Comparative Study of the Industrial Property Laws of ARIPO Member States' (Comparative Study) criticises it for 'its failure to address the vast majority of TRIPS flexibilities' that are available to its members. ${ }^{48}$ These include, among others: the lack of substantive discussion on stringent patentability standards; on the full range of allowable non-inventions and exclusions; on research and education, as well as other exceptions permitted under TRIPS Article 30; on disclosure requirements; on the prerogative of governments to define the grounds for compulsory licences; and on the use of competition policy to address abuse of patents.

\footnotetext{
${ }^{42}$ Khor (2014), p. 13.

${ }^{43}$ Medicines Law and Policy, "The TRIPS Flexibilities Database".

${ }^{44}$ See Gay (2018) https://www.researchgate.net/publication/325206579_Pharmaceutical_Dreams_ TRIPS_and_drugs_policy_in_Bangladesh.

${ }^{45}$ UN Committee for Development Policy (2015) https://www.un.org/ldcportal/wto-drugs-patentwaiver-for-ldcs-extended-until-2033/.

${ }^{46}$ Shashikant (2014) South Centre Research Paper No 56 https://www.southcentre.int/wp-content/ uploads/2014/11/RP56_The-ARIPO-Protocol-on-Patents_ENl.pdf.

${ }^{47}$ Shashikant (2014) South Centre Research Paper No 56, 45.

${ }^{48}$ Baker (n.d.) "A Full description of WTO TRIPS Flexibilities Available to ARIPO Member States and a Critique of ARIPO's Comparative Study Analyzing and Making Recommendations Concerning Those Flexibilities [2019] http://kelinkenya.org/wp-content/uploads/2019/05/ARIPOMember-States-obligations-and-flexibilities-under-the-WTO-TRIPS-Agreement-March-2019.pdf.
} 


\section{A Tale of Two Countries}

This section will focus on two case examples from Southern Africa, regarding neighbouring countries heavily affected by the HIV/AIDS pandemic, and their respective approaches to the use of compulsory licensing and government use for access to medicines.

\subsection{The Zimbabwean Case}

Zimbabwe's compulsory licensing regime presents an interesting legal framework. The primary statute is the Patents Act, ${ }^{49}$ which has undergone three rounds of amendments (in 2001, and twice in 2002) to make it TRIPS-compliant. The Act contains, in addition to provisions for compulsory licensing and government use, special provisions for government use during particular emergencies.

In addition, there is extensive resort to secondary legislation, such as statutory letters or instruments, to support this framework. Statutory instruments are a form of legislation which allow the provisions of an Act of Parliament to be subsequently brought into force without Parliament having to pass a new Act. They are derived from UK law, Zimbabwe having been a former British colony. The Statutory Instrument or Government Notice is thus a form of delegated or subsidiary legislation. ${ }^{50}$ In Zimbabwe, an Act of Parliament may delegate power to a relevant Minister to make statutory instruments ${ }^{51}$ within the scope, and for the purposes, of the particular Act, provided they are consistent with that Act, as well as the Declaration of Rights in Chapter 4 of the country's Constitution. ${ }^{52}$

It should be noted that the range of flexibilities incorporated into the Patents Act includes provisions for: compulsory licensing ${ }^{53}$ and government use; ${ }^{54}$ parallel importation; ${ }^{55}$ early working exception ('test batches') ${ }^{56}$ pre-grant opposition to

\footnotetext{
${ }^{49}$ Patents (Amendment) Act, 1987 Chapter 26:03 (amended by Acts 26/1971, 39/1973 (ss. 39 and 52), 42/1976 (s. 15), 39/1979, 15/1981, 29/1981, 41/1983, 12/1986 (s. 13), 11/1991 (s. 17), 20/1994 (s. 7), 22/2001, 9/2002, 14/2002.)

${ }^{50}$ Statutory Instruments (2008), UK House of Commons Information Office Factsheet L7 Legislative Series https://www.parliament.uk/documents/commons-information-office/107.pdf.

${ }^{51}$ Delegated or Subsidiary Legislation (undated) Zimbabwe Legal Information Institute https:// zimlii.org/content/delegated-or-subsidiary-legislation.

${ }^{52}$ Constitution of Zimbabwe Amendment (No 20) Act (2013). See also, Declaration of Rights (2013), Zimbabwe Human Rights Commission. http://www.zhrc.org.zw/your-rights/.

${ }^{53}$ Patents (Amendment) Act, 1987 Chapter 26:03, ss 30A and 31.

${ }^{54}$ Patents (Amendment) Act, 1987 Chapter 26:03, ss 34 and 35.

${ }^{55}$ Patents (Amendment) Act, 1987 Chapter 26:03, s 24A.

${ }^{56}$ Patents (Amendment) Act, 1987 Chapter 26:03, s 24B.
} 
patents on a wide range of grounds, ${ }^{57}$ and revocation on substantially the same grounds as those for opposition to the grant of a patent. ${ }^{58}$

Exemptions are granted from patenting of diagnostic, therapeutic or surgical methods of treatment; plants, animals, micro-organisms, and essentially biological processes for their production. ${ }^{59}$

The requirements of novelty, inventive step and industrial applicability for the grant of a patent are included as grounds for pre-grant opposition should they not be satisfied, but the Act does not address the patentability criteria in any detail, and does not specifically exclude new uses, or new compounds, combinations or admixtures of a known substance from patenting. Neither are there any exceptions for educational, research, experimental and other uses. A 'relative novelty' standard is applicable, as the Act requires that the invention was 'not known or used in Zimbabwe. ${ }^{60}$

\subsubsection{Compulsory Licences}

The grounds for compulsory licences are limited to: (1) dependent patents, ${ }^{61}$ and (2) several grounds for 'abuse of patent', such as: non-working; failure to meet demand on reasonable terms; refusal to license; and any anti-competitive abuse. ${ }^{62}$ In the second set of instances, an applicant has to demonstrate that he or she has not been able to obtain a licence on reasonable terms within 6 months of a request for a voluntary licence, and on the ground that the reasonable requirements of the public with respect to the invention have not been or will not be satisfied. ${ }^{63}$ The circumstances which will satisfy the latter criterion are deemed to have occurred if:

- the invention, though capable of being worked in Zimbabwe, is not being worked on a commercial scale and there is no satisfactory reason for non-working;

- such working is being prevented by the importation of the patented article by the patentee or associated persons, namely, persons claiming under him, or directly or indirectly purchasing from him, or against whom he is not taking legal action for infringement;

- the demand for the patented article in Zimbabwe is not being met to an adequate extent and on reasonable terms; ${ }^{64}$

\footnotetext{
${ }^{57}$ Patents (Amendment) Act, 1987 Chapter 26:03, s 17.

${ }^{58}$ Patents (Amendment) Act, 1987 Chapter 26:03, s 45.

${ }^{59}$ Patents (Amendment) Act, 1987 Chapter 26:03, s 2A.

${ }^{60}$ Patents (Amendment) Act, 1987 Chapter 26:03, s 2(2)(a).

${ }^{61}$ Patents (Amendment) Act, 1987 Chapter 26:03, s 30A.

${ }^{62}$ Patents (Amendment) Act, 1987 Chapter 26:03, s 31.

${ }^{63}$ Patents (Amendment) Act, 1987 Chapter 26:03, s 31(1).

${ }^{64}$ See also footnote 84 , and accompanying text. In this regard, it is submitted that the reference to 'reasonable terms' could well include 'unreasonable pricing' of a medicine, particularly in the context of the socio-economic conditions in a particular country.
} 
- by the refusal to grant a licence on reasonable terms, trade or industry in Zimbabwe, or that of any persons trading or the establishment of any new trade or industry in Zimbabwe is being prejudiced, and it is in the public interest that licence(s) be granted;

- trade, industry, or any person(s) engaged therein are being prejudiced by unfair conditions attached by the patentee to the purchase, hire, license or use of the patented article or use or working of the patented process;

- any restrictive condition (such as being in restraint of trade or contrary to public policy) has been inserted into a licensing contract for the sale, lease or use of any article or process protected by the patent; and

- a practice by the patent holder has been determined after a judicial or administrative process to be anti-competitive, in which case the requirement for prior negotiation for a voluntary licence is waived. ${ }^{65}$

The procedure for the application for a compulsory licence is relatively workable. It entails a fully motivated application to the Registrar of Patents in the manner prescribed by the Act; permits the patentee or other person to oppose it; and after consideration of all the submissions, the Registrar may grant the application on appropriate terms, or refuse it. ${ }^{66}$ Decisions of the Registrar may be appealed before the Intellectual Property Tribunal. ${ }^{67}$ This entails an essentially administrative procedure with recourse to appeal before a quasi-judicial Tribunal.

In addition, the Act apparently also permits a presumptive licence where a patent is in force in respect of a substance capable of being used as food or medicine or in their production. ${ }^{68}$ This 'necessity' premise is plausible where the invention is a medicine or other public necessity that is not available to the general public or a significant group of patients. The relevant tribunal shall on application, grant a presumptive licence subject to payment of a reasonable and affordable royalty. Other inventions falling into this category include the process for producing such substances, inventions capable of being used as surgical or curative devices, or in the protection of the environment, or those capable of substantially improving the technological, social and economic development of the country. ${ }^{69}$

\subsubsection{Government Use}

By far the strongest flexibility in the Act relates to government use and the special provisions as to State use during an emergency. The essence of this use provision is that 'any department of state or any person authorized in writing by the Minister

\footnotetext{
${ }^{65}$ Patents (Amendment) Act, 1987 Chapter 26:03, ss 31(1), 31(6) and 31(6a).

${ }^{66}$ Patents (Amendment) Act, 1987 Chapter 26:03, ss 31(1) to 31(5).

${ }^{67}$ Patents (Amendment) Act, 1987 Chapter 26:03, s 69.

${ }^{68}$ Patents (Amendment) Act, 1987 Chapter 26:03, s 32(1)(a).

${ }^{69}$ Patents (Amendment) Act, 1987 Chapter 26:03, s 32(1).
} 
(of Justice, Legal and Parliamentary Affairs) may make, use or exercise any invention disclosed in any specification lodged at the Patent Office for the service of the State in accordance with this section. ${ }^{70}$ Section 34(1) is TRIPS-plus to the extent it requires agreement with the patent holder on the terms and conditions of the use, ${ }^{71}$ and appears to contradict section 34(5) (which requires that the patent holder need only be informed). It elaborates that the authority may be given either before or after the patent grant, or either before or after the acts for which the authority is given are done, that is, the authority is retrospective in this regard, presumably with an emergency in mind. Secondly, the authority may be given to any person, whether or not he or she is authorised directly or indirectly by the patentee to make, use, exercise or vend the invention. ${ }^{72}$ The patentee need only be informed timeously and be furnished with any information required, unless it would be contrary to the public interest to do so. ${ }^{73}$

The Act additionally includes 'Special provisions as to State use during emergency ${ }^{74}$ in terms of which the State and authorised parties shall have the power to make, use, exercise and vend the invention for purposes deemed by the Minister necessary or expedient to achieve a number of identified public interest purposes. In the case of access to pharmaceutical inventions, the relevant provisions relate to the following needs: the maintenance, and securing a sufficiency, of supplies and services essential to both the life and well-being of the community; promoting the productivity of industry, commerce or agriculture; fostering and directing exports and reducing imports of any classes, from all or any countries and for redressing the balance of trade; or generally, ensuring that the whole resources of the community are available for use, and are used, in a manner best calculated to serve the interests of the community. ${ }^{75}$

Employing this framework, the Zimbabwean government issued what appears to be the first government use licence on medicines in the post-Doha era. ${ }^{76}$ The licence invokes the following legal provisions:

1. Section 34 of the Patents Act which is the enabling provision for the government use licence (Use of patented inventions for service of the State).

\footnotetext{
${ }^{70}$ Patents (Amendment) Act, 1987 Chapter 26:03, s 34(1).

${ }^{71}$ Patents (Amendment) Act, 1987 Chapter 26:03, s 34(2). TRIPS Article 31(b) waives this condition in cases of national emergency or other circumstances of extreme urgency, or of public non-commercial use.

${ }^{72}$ Patents (Amendment) Act, 1987 Chapter 26:03, ss 34(4)(a) and (b).

${ }^{73}$ Patents (Amendment) Act, 1987 Chapter 26:03, s 34(5).

${ }^{74}$ Patents (Amendment) Act, 1987 Chapter 26:03, s 35.

${ }^{75}$ Patents (Amendment) Act, 1987 Chapter 26:03, ss 35(1)(b), (c), (d), (e) and (f).

${ }^{76}$ Cecilia (2006) Int. J Intellectual Property Management Vol 1 Nos 1/2, 22-36 https://www. researchgate.net/publication/247835566_Compulsory_licences_Recent_experiences_in_develop ing_countries.
} 
2. Section 35 of the Patents Act which enables the declaration of an emergency to override, in this case, antiretroviral patents (Special provisions as to State use during emergency).

3. General Notice 240 of 2002: Declaration of Period of Emergency for an initial period of 6 months commencing 24 May 2002 (reproduced below).

4. Statutory Instrument 32 of 2003 , extending the period of emergency for a further 5 years (from January 2003 to December 2008).

General Notice 240 of 2002

PATENTS ACT [CHAPTER 26:03]

\section{Declaration of Period of Emergency (HIV/AIDS) Notice 2002}

IT is hereby notified that the Minister of Justice, Legal and Parliamentary Affairs has, in terms of section 34 as read with section 35 of the Patents Act [Chapter 26:03] made the following notice:

1. This notice may be cited as the Declaration of Period of Emergency (HIV/AIDS) Notice, 2002.

2. In view of the rapid spread of HIV/AIDS among the population of Zimbabwe, the Minister hereby declares an emergency for a period of six months, with effect from the date of promulgation of this notice, for the purpose of enabling the State or a person authorised by the Minister under section 34 of the Act

(a) to make or use any patented drug, including any antiretroviral drug, used in the treatment of persons suffering from HIV/AIDS or HIV/AIDS related conditions;

(b) to import any generic drug used in the treatment of persons suffering from HIV/AIDS or HIV/AIDS-related conditions.

P. A. CHINAMASA Minister of Justice, Legal and Parliamentary Affairs.

\section{4-5-002}

Once the extended period of emergency had been proclaimed, several companies applied for authorisation to supply antiretrovirals, with a locally-registered company Varichem Pharmaceuticals [Pvt] Ltd being granted authority to 'produce antiretroviral or HIV/AIDS-related drugs and supply three-quarters of its produced drugs to State-owned health institutions' at prices that 'shall be fixed subject to price control mechanisms to be determined by the Minister. ${ }^{77}$ Subsequently, another local company Datlabs, and a local agent Omahn, were authorised to import ARVs from Indian companies Ranbaxy and Cipla, respectively. The authorisation did not

\footnotetext{
${ }^{77}$ As quoted in Cecilia (2006), p. 26.
} 
specify the rate of royalty payable, but it appears that the rate offered was $4 \%$ of the value of the generic medicines actually delivered. ${ }^{78}$

\subsubsection{Lessons}

The provisions discussed above represent an expeditious mechanism to enable access to medicines in the context of a declared public health emergency. A number of important lessons may be drawn from this example.

Firstly the importance of effective enabling legislation, so that clear guidelines are available in the law to institute the use of this flexibility, supplemented by detailed mechanisms in the regulations.

Secondly, an expedient administrative rather than judicial procedure, both for the issuance of a compulsory licence, as well as the operation of the government use licence. It is vital that such a procedure is time-saving and cost-effective.

Thirdly, various other access-friendly considerations were tied in with this public health flexibility, namely: advancing the industrial policy objective of promoting local production; cost-saving measures such as the use of generic medicines; and the employment of price controls to make the medicines affordable to the State.

However, medicines prices generally continue to be high in both the private and public sectors in Zimbabwe, with one study showing that public sector prices were higher than average prices for medicines in seven other African countries, ${ }^{79}$ although subsequent public sector prices for essential medicines have declined. ${ }^{80}$ Since the establishment of the Unitaid Medicines Patent Pool, and the inclusion in its coverage of all WHO-recommended ARVs, all sub-Saharan African countries are included in the category of eligible countries, rendering the use of flexibilities superfluous for such medicines. However, as there are no such licensing arrangements for a range of other highly-priced essential medicines, the need to utilise TRIPS flexibilities continues to exist. ${ }^{81}$

\footnotetext{
${ }^{78}$ Ibid.

${ }^{79}$ See Gavaza et al. (2009), https://www.researchgate.net/publication/51704733_The_prices_ people_pay_for_medicines_in_Zimbabwe.

${ }^{80}$ Marume et al. (2018), https://www.ajol.info/index.php/cajm/article/view/164302.

${ }^{81}$ Hoen et al. (2018), https://joppp.biomedcentral.com/articles/10.1186/s40545-018-0157-7.
} 


\subsection{The South African Case}

\subsubsection{Legal Framework}

Despite the existence of relevant provisions in over a century of patent legislation, ${ }^{82}$ not a single compulsory licence has been granted on a pharmaceutical-related patent in South Africa. ${ }^{83}$ The existing legislation provides for compulsory licences in cases of (1) dependent patents, ${ }^{84}$ and (2) abuse of patents. In the latter case, the following permissible grounds are enumerated:

- The patented invention is not being worked in the country on a commercial scale or to an adequate extent;

- The demand for the patented article is not being met to an adequate extent and on reasonable terms; (One proposed policy option available in this regard is that 'a price charged by the patent holder that bears no reasonable relation to the marginal or average variable cost of manufacturing the item shall be deemed unreasonable.' $)^{85}$

- The refusal to license on reasonable terms prejudices trade, industry or agriculture in the country, and it is in the public interest that a licence be granted; and

- The demand is being met by importation and the price charged is excessive in relation to the price charged in countries of manufacture. ${ }^{86}$

The government use provision states that 'a Minister of State may use an invention for public purposes on such conditions as may be agreed upon with the patentee, or in default of agreement on such conditions as are determined by the commissioner (of patents) on application by or on behalf of such Minister and after hearing the patentee. ${ }^{, 87}$ The requirement of 'on such conditions as may be agreed upon with the patentee' is, of course, TRIPS-plus in that TRIPS Article 31 (b) expressly waives this requirement in certain circumstances, in particular for public non-commercial use.

For reasons that are explored more fully below, which include the problem of AIDS denialism, pressure from the US government and the legal difficulties of

\footnotetext{
${ }^{82}$ Patents Act No 57 of 1978 , s 56 provides a limited number of grounds for the issuance of compulsory licences, and s 4 permits government use (albeit still requiring prior agreement on the terms).

${ }^{83}$ See, for example: Vawda (2018), https://www.southcentre.int/wp-content/uploads/2018/12/ RP90_Compulsory-Licensing-Jurisprudence-in-South-Africa-Do-We-Have-Our-Priorities-Right_ EN-1.pdf; Yousuf A Vawda (2013), "Country Case Study: South Africa. In Correa (2013) https:// www.southcentre.int/wp-content/uploads/2016/05/Bk_2013_Pharmaceutical-innovation_EN.pdf.

${ }^{84}$ Patents Act 57 of 1978, s 55.

${ }^{85}$ See United Nations Development Programme (2013), p. 68.

${ }^{86}$ Patents Act 57 of 1978, ss 56(a), (c), (d) and (e) respectively.

${ }^{87}$ Patents Act, s 4 .
} 
succeeding in compulsory licensing applications, ${ }^{88}$ advocates of access to medicines have had to seek other flexibilities to advance their cause.

It has been said that the key to successful rights litigation is both the framing of access issues as human rights claims, as well as having this framing embedded in domestic law. ${ }^{89}$ Although South African treatment activists have been successful in framing their access to health care and medicines campaigns in terms of human rights norms, they have been less successful in having this paradigm inserted in IP contests in the courts. ${ }^{90}$ Sometimes presented as the use of compulsory licensing in South Africa, ${ }^{91}$ the most successful use of a TRIPS flexibility in the country was the invocation of competition law and policy to challenge excessive prices and refusal to licence key ARVs. In the first 2002 Hazel Tau case, after the Competition Commission found probable violations and prior to the Competition Tribunal considering the Commission's request to grant anti-competition compulsory licences, the patent holders settled by granting licences to multiple generic companies allowing sales throughout the region, thus increasing affordable access to medicines. ${ }^{92}$ The second case, in 2007, involved a complaint against another company on the grounds of refusal to licence. ${ }^{93}$ Here again, the company negotiated voluntary licences, with similar results. ${ }^{94}$

In this instance, not only was the general framing in terms of human rights norms evident, but the legislation in terms of which the complaint had been lodged was expressly grounded in transformative and rights-based terms:

The people of South Africa recognise:

That apartheid and other discriminatory laws and practices of the past resulted in excessive concentrations of ownership and control within the national economy, weak enforcement of anti-competitive trade practices. and unjust restrictions on full and free participation in the economy by all South Africans.

That the economy must be open to greater ownership by a greater number of South Africans.

\footnotetext{
${ }^{88}$ See Sects. 5.2.2, 5.2.3 and 5.2.4 below.

${ }^{89}$ See, for example: Land (2013) https://www.academia.edu/10455316/Human_Rights_Frames_ in_IP_Contests?email_work_card=view-paper; and Berger and Kapczynski (2009) Human Rights Advocacy Stories https://papers.ssrn.com/sol3/papers.cfm?abstract_id=1323522.

${ }^{90}$ See discussion below in respect of the approach of South African courts to employing a human rights lens in IP disputes, despite having a strong Bill of Rights in its Constitution.

${ }^{91}$ See Medicines Law and Policy, "The TRIPS Flexibilities Database".

${ }^{92}$ Hazel Tau and Others v GlaxoSmithKline and Boehringer Ingelheim (Competition Commission) Case No 2002Sep226, in which patients and civil society organisations complained to the Competition Commission that the named pharmaceutical companies had abused their dominant position in the ARV market, refused to license an essential facility, and engaged in excessive pricing. The Commission found against the companies, and its request to the Competition Tribunal was to order compulsory licences. As indicated, the dispute was settled prior to this hearing with the companies agreeing to grant several voluntary licences for the medicines involved.

${ }^{93}$ Treatment Action Campaign v MSD (Pty) Ltd \& Another (November 2007) Competition Commission of South Africa.

${ }^{94}$ United Nations Development Programme (2013), pp. 93-95.
} 
That credible competition law, and effective structures to administer that law are necessary for an efficient functioning economy.

That an efficient, competitive economic environment, balancing the interests of workers, owners and consumers and focussed on development, will benefit all South Africans. ${ }^{95}$

This legal text is significant in that it situates competition law in the context of South Africa's history, distorted by apartheid, and outlines a developmental path to the application of competition law in the country.

\subsubsection{AIDS Denialism}

The unfortunate chapter of AIDS denialism in South Africa's lack of response to the pandemic and the resultant avoidable and unnecessary deaths has now been well documented. ${ }^{96}$ In the context of the government's questioning of the connection between HIV and the resulting disease syndrome as well as the efficacy of ARVs and other medicines having rendered the question of treatment highly controversial, prospects for the use of compulsory licences were remote.

\subsubsection{US Pressure}

Early legal challenges and threats against South Africa, Brazil and Thailand on proposed and purported use of compulsory licences have also been well documented. ${ }^{97}$ In addition, over the past two decades, the US has threatened many countries contemplating such use and routinely placed them on its Special 301 Reports under the US Trade Act of 1974. As commentators have noted, while such threats are usually bluster, it has not stopped some countries (such as India and Brazil) from backing down. ${ }^{98}$ No doubt, such threats have a chilling effect on countries seeking to preserve their trade relations with the US.

The use of TRIPS flexibilities has increasingly come under attack in recent bilateral and regional trade agreements involving the US. In particular, the US has sought to constrain the use of compulsory licensing by, for example, limiting the

\footnotetext{
${ }^{95}$ Competition Act No 89 of 1998, Preamble. The emphasis here is on the final sentence.

${ }^{96}$ See, for example, Nattrass (2005) https://www.sahistory.org.za/sites/default/files/nattrass hivaids_policy.pdf; and Geffen and Cameron (2009) Centre for Social Science Research Aids and Society Research Unit, CSSR Working Paper No 257 https://open.uct.ac.za/bitstream/item/ 22585/Geffen_deadly_hand_denial_2009.pdf?sequence $=1$.

${ }^{97}$ See, for example: Oxfam (2001), https://oxfamilibrary.openrepository.com/bitstream/handle/ 10546/620381/bn-access-to-medicines-south-africa-010201-en.pdf?sequence=1\&isAllowed=y; Ooms and Hanefeld (2019) https://www.bmj.com/content/bmj/365/bmj.12098.full.pdf; and Reichman (2009) https://www.ncbi.nlm.nih.gov/pmc/articles/PMC2893582/.

${ }^{98}$ Baker (2018) https://healthgap.org/dont-be-afraid-of-compulsory-licenses-despite-us-threats-spe cial-301-reports-1998-2017-listing-concerns-but-taking-little-action/.
} 
grounds to: remedying anti-competitive practices, or in cases of public non-commercial use, or of national emergency or other circumstances of extreme urgency (as in the Australia-US Free Trade Agreement). ${ }^{99}$ This strategy 'has been characterised by a progressive "ratcheting up" of IP protections for pharmaceuticals, with provisions intended to prolong monopolies, support high prices and frustrate market entry of generic medicines - all of which undermine access to affordable medicines. ${ }^{100}$

In South Africa, neither the government nor the judiciary appears to have had any appetite for compulsory licences, despite the declarations of its representatives at global fora. ${ }^{101}$

Previous calls by civil society and generic manufacturers on the government to implement the provisions of the Patents Act to this end have gone unheeded. ${ }^{102}$ Currently, patient groups are again engaging the government to issue compulsory licences in respect of newer ARVs, and drugs for use in the treatment of cancer and tuberculosis. $^{103}$

\subsubsection{Judicial Deference}

An analysis of compulsory licence applications on pharmaceutical and chemical products before the Commissioner of Patents (High Court) or the Supreme Court of Appeal of South Africa during the period 1978 - 2018 revealed that not a single compulsory licence had been issued, nor has one been issued since the advent of patent legislation in the country in the early twentieth century. ${ }^{104}$

In summary, the case analysis highlighted the following lines of reasoning adopted by the courts in rejecting such applications:

- The failure on the part of the applicant to discharge the evidentiary burden that the patent had been abused. ${ }^{105}$

- The concept of working a patent included exploitation, which was interpreted widely enough to entail working by importation. ${ }^{106}$

\footnotetext{
${ }^{99}$ See Lopert and Gleeson (2013), pp. 199-223 http://onlinelibrary.wiley.com/doi/10.1111/jlme. 12014/abstract.

${ }^{100}$ Lopert and Gleeson (2013), p. 199.

${ }^{101} \mathrm{See}$, for example, WIPO (2016) https://www.wipo.int/edocs/mdocs/scp/en/scp_25/scp_25_6. pdf.

${ }^{102}$ See, for example, Oxfam (2001), pp. 2-3.

${ }^{103}$ See Medicins Sans Frontieres (2015) https://www.msf.org/south-africa-should-override-patentkey-hiv-medicine-after-widespread-stock-out-problem; and Fix the Patent Laws Campaign (2019) https://www.fixthepatentlaws.org/.

${ }^{104}$ Vawda (2018), p. 90.

${ }^{105}$ Syntheta (Pty) Ltd v Janssen Pharmaceutica NV \& Another 1999 (1) SA 85 SCA.

${ }^{106}$ Sanachem (Pty) Ltd v British Technology Group PLC 1992 BP 276 (CP).
} 
- With regard to the amount of remuneration, that it was not unreasonable to charge a royalty which the trade would carry. ${ }^{107}$

- Regarding negotiating reasonable terms for a licence, the court required evidence indicating, with reasonable precision, what reasonable terms are. ${ }^{108}$

- That a charge of unreasonable terms is not established merely on proof that the compulsory licensing applicant can sell the same sort of article at a lower price. ${ }^{109}$

Absent from this formalistic reasoning were any considerations of the level of development of the country, the socio-economic status of the majority of it population, or the impact of the price of the medicines on access to health care.

Of significance is the manner in which the courts have approached the dispute between the patent holder and patent challenger. Thus, in an application (Aventis) ${ }^{110}$ for, among others, a temporary interdict (injunction) based on an infringement claim against a generic drug manufacturer, the court refused, despite being requested, to consider the impact of the interdict on the supply of medicines and adjudicate the case through the lens of the Constitution and its Bill of Rights. ${ }^{111}$ It further took a rather narrow view on the question of awarding damages (royalties) as an alternative to the interdict, holding that this would be tantamount to granting a compulsory licence. Article 44.2 of the TRIPS Agreement permits this option and there is now strong precedent for the granting of judicial, royalty-bearing licences instead of injunctions from the US Supreme Court. ${ }^{112}$ Even though the court in Aventis acknowledged that the issue of patent validity (which had been challenged) still stood to be determined in revocation proceedings, it refused to accept this less restrictive means of resolving an interim dispute, and appears to have disregarded the social value of the alleged infringing product in its considerations.

There are several other instances of what appear to be deference towards the interests of patent holders. One relates to the anomalous practice in infringement proceedings that, even if it were found that the invention was not patentable, it would remain valid absent a counterclaim for revocation. ${ }^{113}$ The effect of this approach is that in infringement proceedings, even if the defence of invalidity is successful thereby defeating an infringement claim, the patent remains on the register, and the proprietor can sue others on the patent.

Another instance where the prerogatives of the patent holder are prioritised are the so-called interlocutory applications for amendments to patent specifications, where the court has relieved the applicant (the patent holder) of the burden of

\footnotetext{
${ }^{107}$ Sanachem (Pty) Ltd v British Technology Group PLC 1992 BP 276 (CP).

${ }^{108}$ Afitra (Pty) Ltd and Another V Carlton Paper of SA (Pty) Ltd 1992 BP 331 (CP).

${ }^{109}$ Afitra (Pty) Ltd and Another V Carlton Paper of SA (Pty) Ltd 1992 BP 331 (CP).

${ }^{110}$ Cipla Medpro v Aventis Pharma (139/12); Aventis Pharma SA v Cipla Life Sciences (138/12) [2012] ZASCA 108 (26 July 2012).

${ }^{111}$ Constitution of the Republic of South Africa (1996).

112 eBay Inc. v MercExchange, L.L.C. 547 U.S. 388 (2006). See also the Indian High Court decision of Hoffman La Roche v. Cipla \& Anr, IA No. 642/2008 in CS (OS) No, 89.2008.

${ }^{113}$ Strix Ltd v Nu-World Industries (Pty) Ltd 2016 (1) SA 387 (SCA).
} 
providing full reasons for the amendment. ${ }^{114}$ The Bateman judgment cites with approval another decision (Kimberly-Clark), ${ }^{115}$ despite the fact that the latter decision in fact adopts the opposite approach. In addition, this court adopted the approach that 'it is in the public interest that patents should be rectified or validated by way of amendment ${ }^{116}$ without having regard to the impact of the continuing validity of the patent on the broader public interest. Any appreciation of the notion of 'access' as a public interest in relation to an essential product, facility or service is absent.

It is therefore contended that the very architecture of the patent landscape, the rather limited grounds on which an application for a compulsory licence may be brought, combined with the overly formal approach to judicial interpretation and adjudication, including an apparent deference to patent holders over the general public, may be responsible for the dearth of such applications, and hence the lack of their grant. It must be noted in passing that generic manufacturers are unlikely to apply for compulsory licences unless there are sufficient commercial prospects, given that the South African pharmaceuticals market is relatively small. And, as regards those medicines covered by the Medicines Patent Pool, South Africa is already benefiting from this initiative. ${ }^{117}$

\subsubsection{New IP Policy Phase I}

In 2018 after a protracted civil society-led campaign, ${ }^{118}$ the South African Cabinet approved a new IP policy, premised on public health, ${ }^{119}$ in recognition of the abject failure of the present system to adequately meet the need of the general public to access affordable medicines. The IP Policy draws its inspiration from the Constitution of South Africa, and recognises that 'there is a need for a comprehensive IP Policy that will promote a holistic, balanced and coordinated approach to IP that is mindful of the many obligations mandated under the South African Constitution.' The policy expressly recognises the need to reform the regime as it relates to compulsory licences, both in terms of their scope and procedure for application, as well as for the establishment of guidelines for expedited government use. ${ }^{120}$

\footnotetext{
${ }^{114}$ Bateman Equipment Ltd and Another v The Wren Group (Pty) Ltd 2000 (1) SA 649 (SCA).

${ }^{115}$ Kimberly-Clark of South Africa (Pty) Ltd formerly Carlton Paper of South Africa (Pty) Ltd $v$ Proctor \& Gamble (Pty) Ltd (A488/96) [1998] ZASCA 39.

${ }^{116}$ Bateman Equipment Ltd and Another v The Wren Group (Pty) Ltd 2000 (1) SA 649 (SCA).

${ }^{117}$ See footnote 80 and accompanying text.

${ }^{118}$ Baker (2015-16), pp. 309-343 documents the origins of such a campaign.

${ }^{119}$ Republic of South Africa (2018) https://www.thedti.gov.za/news2018/IP_Policy2018-Phase_I. pdf.

${ }^{120}$ Republic of South Africa (2018), p. 28.
} 


\section{Compulsory Licensing Options Under TRIPS}

As indicated, ${ }^{121}$ the TRIPS Agreement does not limit the grounds upon which licences can be granted. The robust discourse over the last two decades around the use of TRIPS flexibilities and, in particular compulsory licensing, had provided policy-makers, legislators and advocacy groups with a panoply of options to consider $^{122}$ in relation to various aspects of this flexibility: broad grounds, easy-to-use procedures, and royalty guidelines and rates that are not so onerous that they frustrate generic competition and hence access to affordable medicines.

\subsection{Expanded Grounds for Compulsory Licences}

The expanded grounds for the issuance of compulsory licences that may be considered are:

- The patent is not worked or not fully worked in the country by the patent holder including that the invention is not available to the public at a reasonably affordable price; or that it has not been worked locally other than by importation and the patent holder fails to demonstrate that it is not economically or technologically feasible to manufacture it in whole or in part in the country;

- The patent is worked by the patent holder or licensee in a form and by means that are harmful to or abusive of the public interest;

- The price charged by the patent holder bears no reasonable relation to the marginal or average variable cost of manufacturing the item and is deemed to be unreasonable;

- The patent can be worked locally on a feasible economy of scale and may benefit the general public; or through a licence granted for importation where it is considered advantageous to do so;

- There is an emergency or other urgent matter of national interest, in which case prior negotiation for a licence on reasonable commercial terms is not required;

- There is a risk of supply interruptions of essential products such as medicines;

- There is a need to promote local production and technology transfer;

- There is any other public interest or public health need;

- The patent holder has been found to have engaged in an anti-competitive practice;

- Where the invention, being a medicine or other public necessity, is not available to the general public or a significant group of patients, the relevant tribunal is

\footnotetext{
${ }^{121}$ See Sect. 3 above.

${ }^{122}$ These options are drawn primarily from United Nations Development Programme (2013), pp. 57-71; Baker and Vawda (2017), pp. 40-60 https://www.fixthepatentlaws.org/submission-byuniversity-of-kwazulu-natal-affiliated-academics-on-sa-draft-intellectual-property-policy/.
} 
enabled to grant, on application, a presumptive licence subject to a reasonable and affordable royalty;

- Where the country lacks sufficient capacity to produce a medicine patented in that country, a compulsory licence may be issued for the importation of the product; and conversely for a compulsory licence to be issued in the manufacturing country where that medicine is under patent, for the purpose of supplying a country with insufficient manufacturing capacity, in terms of a streamlined, easy-to-use procedure. Alternatively, to adopt Article 31bis of the TRIPS Agreement and the Annex to it;

- The grant of a judicial licence in cases alleging infringement, as a satisfactory and less restrictive alternative to the grant of an interdict or injunction;

- Where it is not possible to execute the licence granted on any of the foregoing grounds based on patent disclosures alone, a compulsory licence may be granted on otherwise confidential manufacturing know-how, subject to prior negotiation, payment of reasonable royalty, and non-exclusivity and non-assignability; and

- Where a product is already on the market while the patent application regarding a needed invention (such as a medicine to respond to an epidemic) is still pending, a provisional compulsory licence may be granted to take effect when the relevant patent/s are granted.

\subsection{Government Use}

With regard to government use licences, these need to be expeditious and easy to implement. The following formulation has been proposed: ${ }^{123}$

- Any properly designated public official or government contractor, domestic or foreign, receiving the authorisation or consent of the government of a country, may make public, non-commercial use of a patent.

- No prior negotiation with the patent holder is required, it being necessary only to promptly notify the holder of such use.

- For the purposes of this provision, the use or manufacture of an invention described in and covered by a patent granted in the country by a contractor, sub-contractor, or any person, firm or corporation for the government and with the authorisation or consent of the government, shall be construed as use for that country.

$\overline{{ }^{123} \text { Baker and Vawda (2017), pp. } 47-49 .}$ 


\subsection{Adequate Remuneration}

As regards remuneration of the right holder, TRIPS Article 31(f) requires adequate remuneration based on the economic value of the licence in the country issuing it. The following formulation has been proposed: ${ }^{124}$

- Remuneration Guidelines shall specify a normal royalty of $4 \%$ of wholesale cost, with an upward adjustment of no more than $2 \%$ based on disclosed, extraordinary research and development costs or therapeutic breakthrough in the case of pharmaceuticals. The rate could be adjusted downwards by the same margin based on the use of public funds in the research, or if the holder has already recovered significantly more than its research and development costs as adjusted for risk and opportunity costs.

\subsection{Procedures for Compulsory Licensing Applications}

As indicated, procedures for compulsory licensing should be expeditious and easyto-use. Expedited administrative procedures, rather than judicial processes, which are both more time-consuming and expensive, should be used. The TRIPS Agreement requires judicial process only in relation to independent administrative review in respect of the legal validity of a licence and the amount of remuneration. ${ }^{125}$ The following formulation has been proposed: ${ }^{126}$

- Examination of an application for a compulsory licence shall be conducted by the relevant authority or tribunal.

- The relevant authority or tribunal shall by notice summon the patent holder and applicant to hear their evidence and opinions, and shall stipulate time periods for the submission of evidence, opinions and other matter.

- Should the patent holder not respond to the notice within 2 months, the patent holder will be presumed to have no objection to the issuance of the compulsory licence.

\subsection{Collaboration and Cooperation in the Issuance of CLS}

Finally, there are significant benefits to cooperation between countries on the issuance of compulsory licences. Groups of developing countries could, for example, pool their procurement needs and coordinate the proposed use of compulsory

\footnotetext{
${ }^{124}$ Baker and Vawda, "Submission by University of KwaZulu-Natal-Affiliated Academics", 56-58.

${ }^{125}$ TRIPS Agreement, art 31(i) and (j).

${ }^{126}$ Baker and Vawda (2017), pp. 58-60.
} 
licences for selected medicines, thereby generating sufficient economies of scale to make it viable for generic manufacturers to enter those markets. ${ }^{127}$

An interesting variant of this approach is that permitted by Article 31 bis of TRIPS:

With a view to harnessing economies of scale for the purposes of enhancing purchasing power for, and facilitating the local production of, pharmaceutical products: where a developing or least developed country WTO Member is a party to a regional trade agreement ... at least half of the current membership of which is made up of countries presently on the United Nations list of least developed countries, the obligation of that Member under Article 31(f) shall not apply to the extent necessary to enable a pharmaceutical product produced or imported under a compulsory licence in that Member to be exported to the markets of those other developing or least developed country parties to the regional trade agreement that share the health problem in question. It is understood that this will not prejudice the territorial nature of the patent rights in question. ${ }^{128}$

Thus, for example, all member states of the Southern African Development Community can benefit from this collaborative and pooled procurement mechanism, as 9 of the 15 members are LDCs, ${ }^{129}$ or those of the East African Community as well, with 4 of its 5 WTO-member states being LDCs.

A strong case has been made that, for African countries to make optimal use of compulsory licensing, they must develop strong manufacturing capacity in the pharmaceutical sector. This is imperative because, as the emerging economies in Asia have begun 'to implement a more protectionist intellectual property framework, Africa is ill-advised to continue relying on generic manufacturers in Asia for access to affordable pharmaceuticals. ${ }^{130}$ The African Union's Pharmaceutical Manufacturing Plan for Africa ${ }^{131}$ has increasingly been promoting national and regional collaboration in order to achieve greater self-sufficiency and a sustainable supply of pharmaceuticals for the continent.

\subsection{A Compulsory Licensing Facility}

Another novel proposal to address the inadequate and uncoordinated use of compulsory licensing is that of the establishment of a compulsory licensing facility or consortium (CL Facility). ${ }^{132}$ In a submission to the UN Secretary-General's High

\footnotetext{
${ }^{127}$ See Reichman (2009), pp. 247-263.

${ }^{128}$ TRIPS Agreement, art 31 bis 3.

${ }^{129}$ Hoen et al. (2018).

${ }^{130}$ Owoeye (2014), pp. 92, 217 http://www9.who.int/bulletin/volumes/92/3/13-128413/en/.

${ }^{131}$ African Union (2012), https://apps.who.int/medicinedocs/documents/s20186en/s20186en.pdf.

${ }^{132}$ See Baker (2016a) http://www.unsgaccessmeds.org/inbox/2016/2/27/brook-baker?rq=brook\% 20baker; Baker (2016b) http://www.unsgaccessmeds.org/inbox/2016/2/26/z73kpodxk4jw96mhqe 2 tivq0sd1g3v.
} 
Level Panel on Access to Medicines, the aims of the proposed CL Facility are stated as being to:

- undertake a series of analyses on all possible options for compulsory licences, the conditions and circumstances of their use, and their implications for access to medicines;

- develop and support the implementation of model legislation effectuating the optimal use of compulsory licences and government use orders; provide technical and advocacy assistance for their adoption and use both nationally and regionally (to enable aggregated markets to sustain production and access to medicines).

\section{Conclusion}

Developing countries and LDCs, particularly, face many challenges with both the domestication and also the implementation of TRIPS flexibilities, including compulsory licences and government use. Many of these are not insurmountable, such as the need for political will, the ability to resist trade and political pressures, and the engagement of appropriate technical assistance. In some instances, such as in South Africa, there is the additional reluctance of the judicial system to apply access-friendly interpretations of IP law in line with its Constitution and Bill of Rights.

In the two case studies presented here, the prospects for the use of compulsory licensing and government use are not encouraging. Although Zimbabwe used this flexibility in the instances cited more than 10 years ago, it has not done so since then. In South Africa, it has never been used despite many compelling circumstances and strong appeals. There is great expectation that the new IP Policy, once legislated, ought to clear the path for easy use of these forms of licensing. Thereafter it will be entirely up to the political will of government to act on the legislation.

The current COVID-19 pandemic has brought into sharp relief the inequality that exists both among countries of the world, and within them. Access to any vaccines and other therapies that may be developed cannot be guaranteed, because they are likely to be protected by various forms of intellectual property rights, and hence only be available at a high cost. In this context, compulsory licensing and government use remain an important option for, particularly, developing and least developed countries to ensure access to such health technologies. 


\section{References}

\section{Cases}

\section{South Africa}

Afitra (Pty) Ltd and Another V Carlton Paper of SA (Pty) Ltd 1992 BP 331 (CP)

Bateman Equipment Ltd and Another v The Wren Group (Pty) Ltd 2000 (1) SA 649 (SCA)

Cipla Medpro v Aventis Pharma (139/12); Aventis Pharma SA v Cipla Life Sciences (138/12) [2012] ZASCA 108 (26 July 2012)

Hazel Tau and Others v GlaxoSmithKline and Boehringer Ingelheim (Competition Commission) Case No 2002Sep226

Kimberly-Clark of South Africa (Pty) Ltd formerly Carlton Paper of South Africa (Pty) Ltd v Proctor \& Gamble (Pty) Ltd (A488/96) [1998] ZASCA 39

Sanachem (Pty) Ltd v British Technology Group PLC 1992 BP 276 (CP)

Strix Ltd v Nu-World Industries (Pty) Ltd 2016 (1) SA 387 (SCA)

Syntheta (Pty) Ltd v Janssen Pharmaceutica NV \& Another 1999 (1) SA 85 SCA

Treatment Action Campaign v MSD (Pty) Ltd \& Another (November 2007) Competition Commission of South Africa

\section{USA}

eBay Inc. v MercExchange, L.L.C. 547 U.S. 388 (2006)

\section{India}

Hoffman La Roche v. Cipla \& Anr, IA No. 642/2008 in CS (OS) No, 89.2008 (India)

\section{Statutes and Statutory Instruments}

\section{International}

Declaration on the TRIPS agreement and public health [WTO]. https://www.wto.org/english/ thewto_e/minist_e/min01_e/mindecl_trips_e.htm. Accessed 23 Feb 2021

International Covenant on Economic Social and Cultural Rights. https://www.ohchr.org/ Documents/ProfessionalInterest/cescr.pdf. Accessed 23 Feb 2021

Paris Convention for the Protection of Industrial Property of March 20, 1883. https://www.wipo.int/ edocs/lexdocs/treaties/en/paris/trt_paris_001en.pdf. Accessed 23 Feb 2021

Trade-Related Aspects of Intellectual Property Rights [WTO]. https://www.wto.org/english/docs e/legal_e/27-trips_03_e.htm. Accessed 23 Feb 2021

Universal Declaration of Human Rights. https://www.ohchr.org/EN/UDHR/Documents/UDHR_ Translations/eng.pdf. Accessed 23 Feb 2021 


\section{United Kingdom}

Patents, Designs, and Trade Marks Act of 1883, s 27(2) https://archive.org/stream / patentsdesignsa01britgoog/patentsdesignsa01britgoog_djvu.txt. Accessed 23 Feb 2021

Statutory Instruments (2008) UK House of Commons Information Office Factsheet L7 Legislative Series https://www.parliament.uk/documents/commons-information-office/107.pdf. Accessed $23 \mathrm{Feb} 2021$

\section{South Africa}

Constitution of the Republic of South Africa, 1996

Patents Act No 57 of 1978

\section{Zimbabwe}

Constitution of Zimbabwe Amendment (No 20) Act, 2013

Declaration of Rights (2013) Zimbabwe Human Rights Commission. http://www.zhrc.org.zw/yourrights/. Accessed 23 Feb 2021

\section{Books}

Correa CM (ed) (2013) Pharmaceutical innovation, incremental patenting and compulsory licensing. South Centre, Geneva. https://www.southcentre.int/wp-content/uploads/2016/05/Bk_ 2013_Pharmaceutical-innovation_EN.pdf. Accessed 23 Feb 2021

Khor M (2014) Compulsory license and "Government Use" to promote access to medicines: some examples. Third World Network 24

May C, Sell SK (2006) Intellectual property rights: a critical history. Lynne Rienner Publishers, Boulder

\section{Contributions to Edited Books}

Vawda YA (2013) Country case study: South Africa. In: Correa CM (ed) Pharmaceutical innovation, incremental patenting and compulsory licensing. South Centre, Geneva. https://www. southcentre.int/product/pharmaceutical-innovation-incremental-patenting-and-compulsorylicensing/. Accessed 23 Feb 2021

\section{Journal Articles}

Baker BK (2015-16) International collaboration on IP and access to medicines: the birth of the S. Africa fix the patents law campaign. NYLS Law Rev 60:309-343

Brennan $\mathrm{H}$ et al (2016) A prescription for excessive drug pricing: leveraging 
Cecilia O (2006) Compulsory licences: recent experiences in developing countries. Int. J Intellect Property Manag 1(1/2):22-36. https://www.researchgate.net/publication/247835566_Compul sory_licences_Recent_experiences_in_developing_countries. Accessed 23 Feb 2021

Government Patent Use for Health (2016) Yale J Law Technol 18: 275 https://yjolt.org/sites/ default/files/kapczynski_18yjolt275_gk_0_0.pdf. Accessed 23 Feb 2021

Hoen E't et al (2018) Patent challenges in the procurement and supply of generic new essential medicines and lessons from HIV in the Southern African Development Community (SADC) region. J Pharm Policy Practice. https://joppp.biomedcentral.com/articles/10.1186/s40545-0180157-7. Accessed 23 Feb 2021

Lopert R, Gleeson D (2013) The high price of 'Free' trade: US trade agreements and access to medicines. J Law Med Ethics 41(1):199-223. http://onlinelibrary.wiley.com/doi/10.1111/jlme. 12014/abstract. Accessed 23 Feb 2021

Ooms G, Hanefeld J (2019) Threat of compulsory licences could increase access to essential medicines. BMJ. https://www.bmj.com/content/bmj/365/bmj.12098.full.pdf. Accessed 23 February 2021

Reichman JH (2009) Compulsory licensing of patented pharmaceutical inventions: evaluating the options. J Law Med Ethics. https://www.ncbi.nlm.nih.gov/pmc/articles/PMC2893582/. Accessed 23 Feb 2021

Vawda YA, Baker BK (2013) Achieving social justice in the human rights/intellectual property debate: Realising the goal of access to medicines. Afr Human Rights Law J. http://www.scielo. org.za/scielo.php?script=sci_arttext\&pid=S1996-20962013000100004\#top119. Accessed $23 \mathrm{Feb} 2021$

\section{Online Journals}

Berger JM, Kapczynski A (2009) The story of the TAC case: the potential and limits of socioeconomic rights litigation I South Africa. Human Rights Advocacy Stories. https://papers.ssrn. com/sol3/papers.cfm?abstract_id=1323522. Accessed 23 Feb 2021

Correa CM (1999) Intellectual property rights and the use of compulsory licences: options for developing countries. South Centre, Geneva, Trade-Related Agenda, Development and Equity, Working Papers https://www.iatp.org/sites/default/files/Intellectual_Property_Rights_and_the_ Use_of_Co.pdf. Accessed 23 Feb 2021

Correa CM (2019) Will the amendment to the TRIPS agreement enhance access to medicines?" South Centre Policy Brief N0 57 https://www.southcentre.int/wp-content/uploads/2019/01/ PB57_Will-the-Amendment-to-the-TRIPS-Agreement-Enhance-Access-to-Medicines_EN-1. pdf. Accessed 23 Feb 2021

Correa CM, Velasquez G (2019) Access to medicines: experiences with compulsory licenses and government use - the case of Hepatitis C. South Centre Research Papers 85. https://www. southcentre.int/wp-content/uploads/2019/04/RP85_Access-to-Medicines-Experiences-withCompulsory-Licenses-and-Government-Use-The-Case-of-Hepatitis-C_EN.pdf. Accessed $23 \mathrm{Feb} 2021$

Editorial (2012) Compulsory licensing: background. Thailand J Law Policy. http://thailawforum. com/articles/Trips-and-access-to-medicines-India-and-Thailand-2.html. Accessed 26 Jan 2020

Gavaza P et al (2009) The prices people pay for medicines in Zimbabwe. Central Afr J Med. https:// www.researchgate.net/publication/51704733_The_prices_people_pay_for_medicines_in_Zim babwe. Accessed 23 Feb 2021

Gay D (2018) Pharmaceutical dreams: TRIPS and drugs policy in Bangladesh” https://www. researchgate.net/publication/325206579_Pharmaceutical_Dreams_TRIPS_and_drugs_policy_ in_Bangladesh. Accessed 23 Feb 2021 
Geffen N, Cameron E (2009) The deadly hand of denial: Governance and politically-instigated denialism in South Africa", Centre for Social Science Research Aids and Society Research Unit, CSSR Working Paper No 257 https://open.uct.ac.za/bitstream/item/22585/Geffen_deadly_ hand_denial_2009.pdf? sequence $=1$. Accessed 23 Feb 2021

Land M (2013) Human Rights Frames in IP Contests (uncorrected proof). Oxford University Press, Oxford. https://www.academia.edu/10455316/Human_Rights_Frames_in_IP_Contests?email_ work_card=view-paper . Accessed 23 Feb 2021

Marume A et al (2018) Price and availability survey of essential medicines in the Harare province, Zimbabwe. Central African J Med. https://www.ajol.info/index.php/cajm/article/view/164302. Accessed 23 Feb 2021

Shashikant S (2014) The African Regional Intellectual Property Organization (ARIPO) Protocol on patents: implications for access to medicines" South Centre Research Paper No 56 https://www. southcentre.int/wp-content/uploads/2014/11/RP56_The-ARIPO-Protocol-on-Patents_EN1.pdf. Accessed 23 Feb 2021

Vawda YA (2018) Compulsory licensing jurisprudence in South Africa: do we have our priorities right?" South Centre Research Papers 90 https://www.southcentre.int/wp-content/uploads/ 2018/12/RP90_Compulsory-Licensing-Jurisprudence-in-South-Africa-Do-We-Have-Our-Prior ities-Right_EN-1.pdf. Accessed 23 Feb 2021

Wibulpolprasert S, et al (2011) Government use licences in Thailand: The power of evidence, civil movement and political leadership" https://www.ncbi.nlm.nih.gov/pmc/articles/PMC3180369/. Accessed 23 Feb 2021

\section{Command Articles and Law Commission Reports}

African Union (2012) Pharmaceutical Manufacturing Action Plan for Africa Business Plan, https:// apps.who.int/medicinedocs/documents/s20186en/s20186en.pdf. Accessed 23 Feb 2021

Max Planck Institute (2014) Declaration on Patent Protection: Regulatory Sovereignty under TRIPS, 9 https://www.mpg.de/8133454/Patent-Declaration1.pdf. Accessed 23 Feb 2021

Oxfam (2001) South Africa vs. the Drug Giants - A Challenge to Affordable Medicines. Oxfam Background Briefing February 2001 https://oxfamilibrary.openrepository.com/bitstream/han dle/10546/620381/bn-access-to-medicines-south-africa-010201-en.pdf?sequence $=1 \&$ isAllowed $=\mathrm{y}$. Accessed $23 \mathrm{Feb} 2021$

Republic of South Africa (2018) Intellectual Property Policy of the Republic of South Africa Phase I https://www.thedti.gov.za/news2018/IP_Policy2018-Phase_I.pdf. Accessed 23 Feb. 2021

UN Committee for Development Policy (2015) WTO drugs patent waiver for LDCs extended until 2033 https://www.un.org/ldcportal/wto-drugs-patent-waiver-for-ldcs-extended-until-2033/. Accessed 23 Feb 2021

United Nations (2016) Secretary-general's high level panel on access to medicines report: promoting innovation and access to health technologies. http://www.unsgaccessmeds.org/final-report. Accessed 23 Feb 2021

United Nations Development Programme (2013) Using law to accelerate treatment access in South Africa: an analysis of patent. Compet Med Law 39. https://www.undp.org/content/dam/ undp/library/hivaids/English/using_law_to_accelerate_treatment_access_in_south_africa_ undp_2013.pdf. Accessed 23 Feb 2021

WIPO (2016) Standing Committee on the Law of Patents, Twenty-Fifth Session. https://www.wipo. int/edocs/mdocs/scp/en/scp_25/scp_25_6.pdf. Accessed 23 Feb 2021

WIPO (2017) Constraints Faced by Developing Countries and Least Developed Countries (LDCs) in Making Full Use of Patent Flexibilities and Their Impacts on Access to ffordable Especially Essential Medicines for Public Health Purposes in Those Countries: Supplement to Document 
SCP/26/5 WIPO Stnding Committee on the Law of Patents https://www.wipo.int/edocs/mdocs/ scp/en/scp_27/scp_27_6.pdf, 3. Accessed 23 Feb 2021

\section{Websites and Blogs}

Baker B (2016a) Health gap submission to the UNSG's high level panel on access to medicines (1) (unsgaccessmeds.org) http://www.unsgaccessmeds.org/inbox/2016/2/27/brook-baker? rq=brook\%20baker. Accessed 23 Feb 2021

Baker B (2016b) Submission to UN Secretary-General's High Level Panel on Access to Medicines"(2) (unsgaccessmeds.org) http://www.unsgaccessmeds.org/inbox/2016/2/26/ z73kpodxk4jw96mhqe2tivq0sd1g3v. Accessed $23 \mathrm{Feb} 2021$

Baker B (2018) Don't Be Afraid of Compulsory Licenses Despite US Threats: Special 301 Reports 1998-2017 - Listing Concerns But Taking Little Action" (HealthGap) https://healthgap.org/ dont-be-afraid-of-compulsory-licenses-despite-us-threats-special-301-reports-1998-2017-list ing-concerns-but-taking-little-action/. Accessed 23 Feb 2021

Baker BK (n.d.) A Full Description of WTO TRIPS Flexibilities Available to ARIPO Member States and a Critique of ARIPO's Comparative Study Analyzing and Making Recommendations Concerning Those Flexibilities. https://www.bu.edu/gdp/files/2020/05/ARIPO-Member-Statesobligations-andflexibilities-under-the-WTO-TRIPS-Agreement-March-2019.pdf

Baker BK, Vawda YA (2017) Submission by University of KwaZulu-Natal-Affiliated Academics on The Draft Intellectual Property Policy of the Republic of South Africa Phase 1", 40-60. https://www.fixthepatentlaws.org/submission-by-university-of-kwazulu-natal-affiliated-aca demics-on-sa-draft-intellectual-property-policy/. Accessed 23 Feb 2021

Fix the Patent Laws Campaign (2019) Minister Mkhize must ensure access to cancer medicine that WHO now considers "essential"'. https://www.fixthepatentlaws.org/. Accessed 23 Feb 2021

Medicines Law and Policy, "The TRIPS Flexibilities Database" http://tripsflexibilities. medicineslawandpolicy.org/. Accessed 23 February 2021

Medicins Sans Frontieres (2015) South Africa should override patent on key HIV medicine after widespread stock out problem: Press Release https://www.msf.org/south-africa-shouldoverride-patent-key-hiv-medicine-after-widespread-stock-out-problem. Accessed 23 Feb 2021

Nattrass N (2005) "AIDS Policy in Post-Apartheid South Africa" (SA History Online) https://www. sahistory.org.za/sites/default/files/nattrass_hivaids_policy.pdf. Accessed 23 Feb 2021

Owoeye OA (2014) Compulsory patent licensing and local drug manufacturing capacity in Africa". Bulletin of the WHO, 92, $217 \mathrm{http}: / /$ www9.who.int/bulletin/volumes/92/3/13-128413/en/ Accessed 23 Feb 2021

Recommendations Concerning Those Flexibilities (2019). http://kelinkenya.org/wp-content/ uploads/2019/05/ARIPO-Member-States-obligations-and-flexibilities-under-the-WTO-TRIPSAgreement-March-2019.pdf. Accessed 23 Feb 2021

South Centre, "Compulsory Licences and Government Use of Patented Medicines: Precedents Relevant to Address COVID-19" https://ipaccessmeds.southcentre.int/covid-19-pandemic/. Accessed 23 Feb 2021

Zimbabwe Legal Information Institute, "Delegated or Subsidiary Legislation" (undated) https:// zimlii.org/content/delegated-or-subsidiary-legislation. Accessed 23 Feb 2021, Chapter 4 
Open Access This chapter is licensed under the terms of the Creative Commons Attribution 4.0 International License (http://creativecommons.org/licenses/by/4.0/), which permits use, sharing, adaptation, distribution and reproduction in any medium or format, as long as you give appropriate credit to the original author(s) and the source, provide a link to the Creative Commons license and indicate if changes were made.

The images or other third party material in this chapter are included in the chapter's Creative Commons license, unless indicated otherwise in a credit line to the material. If material is not included in the chapter's Creative Commons license and your intended use is not permitted by statutory regulation or exceeds the permitted use, you will need to obtain permission directly from the copyright holder. 